DOI: http://dx.doi.org/10.11157/sites-vol13issiid328

- ARTICLE -

\title{
MULTIPLE PERIPHERALS ONE COSMOPOLITANISM: RIGHTS BASED FEMINISM AND THE GLOBE TROTTING PICK UP ARTIST
}

Brigitte Lewis $^{1}$

\begin{abstract}
This essay is a critical reading of Nigel Rapport's work on cosmopolitan theory in anthropology, specifically the book Anyone: The Cosmopolitan Subject of Anthropology (Rapport 2012). Reading Rapport's work 'against the grain', I explore the androgynous quality of his notion of an anthropological cosmopolitanism. Although I do note that in person at the dinner for the Australian and New Zealand Anthropological Societies Annual Conference in 2015 Rapport explained to me that Anyone really could be anyone, any body, any gender, any sexuality and this was his vision. Buoyed by this assurance I went back to his book but found the female subject to be either side stepped or made invisible by the emphasis on the male identified Anyone called up in his work. Using this particular example, I move onto an exploration of why cosmopolitanism as an ideology is not a useful paradigm in which to base or explain what Niamh Reilly $(2007,180)$ calls 'emancipatory political practice'. I will highlight why I think this is the case using the example of the global organisation known as Pick Up Artists (PUA) and in turn argue for a human rights based feminism as a much more productive framework from which to theorise and practice - a project that has the capacity to unify otherwise divergent subject positions that traverse national, racial, sexual and class distinctions.
\end{abstract}

\section{INTRODUCTION}

In tying to the theme of this edition I am underpinning my essay with the belief that a feminist analysis of cosmopolitanism is a peripheral act because it comes from the borderlands of who is considered a cosmopolitan subject. The concept of 'borderlands' came to prominence with Gloria Anzaldua's (1987) book titled Borderlands/La Frontera: The New Mestiza. Also of note is Chandra Talpade Mohanty's (2003) Feminism Without Borders, and the collection by Clara Roman-Odio and Marta Sierra’s (2011) Transnational Borderlands 
in Women's Global Networks. Anzaldua describes the borderland as a vague and undetermined place created by the emotional residue of 'an unnatural boundary' (Anzaldua 1987,3). It is here, in the borderlands that a cosmopolitan 'someone' who is not 'Anyone' ends up residing. In this instance, I am arguing that it is not women generally who become 'Anyone,' but that they predictably become the Other to the 'Anyone' that is the predictable (masculinist) Self of history past, and, unfortunately present. This point will become clearer as my argument unfurls. Making the political personal, 'Anyone' is also not a lesbian woman, as I am. In addition, I will argue that cosmopolitanism as an androgynous ideology comes to embody Michael Herzfeld's $(2005,3)$ concept of cultural intimacy. That is, the recognition of those aspects of cultural identity that are considered a source of external embarrassment but that nevertheless provide insiders with their assurance of common sociality (Herzfeld 2005, 3). This article is my white, lesbian, middle class (sessional casual academic) Australian, gendered female, able-bodied 'conscious knowledge production' (McClaurin $2001,1)$. It is conscious insofar that I explicitly recognise the various positions I occupy as a subject in the world.

\section{THE COSMOPOLITANISM 'ANYONE'}

Cosmopolitanism as an ideology, according to Nigel Rapport's $(2012,2)$ book Anyone: The Cosmopolitan Subject of Anthropology is 'a social medium which would everywhere afford Anyone the space to live according to the fulfilment of his or her capacities to author an individual life - individual world views, identity and life project and the right and encouragement so to do: the right to be universally recognised as himself or herself (sic) and not merely as a member of a social category or class'. Ironically though, such gendered statements negate recent discussions about gender asymmetry and its need to be broken down by moving away from exclusive categories of his/her. Lewin says of her 2006 feminist anthropological collection that 'dichotomised distinctions based on economic development, cultural boundaries, sexuality, and gender itself all become subjects of investigation rather than assumptions that organise basic questions' (Lewin 2006, 28). Rapport and much of anthropology at large seems to have missed this decree that is loudly being asserted by the Transgender movement as captured by David Valentine's (2007) research and the increasingly popular identity of non binary personhood, blazed by celebrities such as American singer Miley Cyrus and Australian model and DJ Ruby Rose (Holloway 2015).

Rapport goes on to say that, 'the cosmopolitan project is to know Anyone in terms of a universal human nature and at the same time an individual embodi- 
ment: to do justice to his or her universal capacities as well as to their singular expression' (Rapport 2012, 2). However, as we know, many cultures do not recognise an individual self so readily and prefer to speak of the dividual (Strathern 1988). The concept of the dividual as originally forwarded by Strathern is usually understood in opposition to the western-centric bounded individual for whom a self is quite literally self-contained. Thus, the dividual comes to embody a more collective social and theoretical understanding of personhood in that it does not end at the bounds of the individual person but parts of the self are always already connected to others whether these be through obligation, cultural stories, spiritual/religious ideology, understandings of self or consumption. An interesting discussion of the way Christian selves can be considered dividual or what Mark Mosko calls partible selves can be found in his many papers on the subject such as 'Unbecoming Individuals' (Mosko 2015). The main point I am trying to make though is that not all individuals, not all embodiments, not all genders are considered, treated, or thought to be equal, even if in theory it is argued otherwise. And in this case, while Rapport argues for the universal idea of Anyone with individual and therefore multiple understandings of embodiment, this individual or Anyone does not exist anywhere in the world because they are always bound by categories of social difference and hierarchies of power that shove them into identities and markers of very specific selves which is particularly true for women in the traditional biological sense and the more fluid definition in which any body, no matter their sex at birth can identify as woman. As Reilly argues, 'it is vital to challenge false universalisation through emancipatory political projects and not solely in the realm of metaphysics' (Reilly 2007, 183).

Despite these critiques, it is very easy to be drawn into the utopian ideology that cosmopolitanism purports, it is idealistic, it attempts to include every body and anyone. It is the kind of world I want to live in in practice. But theory often falls down in practice. It is telling that in Rapport's introduction to his book he names no less than twenty-two cosmopolitanisms, including, plural discrepant cosmopolitanism, pre-modern and modern cosmopolitans, urban Caribbean cosmopolitans, working-class Pakistani cosmopolitan migrants and cosmopolitan imaginations (Rapport 2012, 1), but no feminist or women centred ones. He says, so that it is not obscured or distorted by cultural prejudices, social structures or historical contingencies, a cosmopolitan anthropology works to elucidate this dialectical relation (Rapport 2012, 2). However, the subject of women is blindingly absent, considering that women are roughly 50 per cent of the world's population (The World Bank Group 2016). This, makes their explicit exclusion offensive, especially with a list so painstakingly researched and long. Yes, the tie between Anyone and humankind - microcosm to mac- 
rocosm - is immanent and irreducible (Rapport 2012, 4) but it is also embedded in gender relations, race relations and hierarchies as I have been arguing. Even in anthropological collections that attempt to include a broad spectrum of positions and academics like United in Discontent (Theodossopoulos and Kirtsoglou 2010) and Whose Cosmopolitanism?: Critical Perspectives, Relationalities and Discontents (Schiller and Irving 2014) where female authors have been included; there has still been very little discussion of gender, an echo of feminist critique since the now classic Woman, Culture, Society by Rosaldo and Lamphere was published in 1974. When we find it hard to include basic critiques of gender as a social category let alone a varied, multi-positional, reflection of all the varieties of womanhood that exist today, we know we still have a very long way to go. And the ideologies we look to, and the academics we look towards to take us forward, must be cognisant of the way in which they are producing and reproducing particular kinds of social power and hegemonic arrangements in the discourse they utilise for theorising about the world and themselves.

We cannot just sweep away these concerns, in what feels like a return to Foucault's and anthropology's historically androcentric subject. Rapport's Anyone reads as a call for freedom from an already privileged male subject position (including his case study Rickey Hirsch). Using this case study, Rapport draws up a comparison to Nazi ideology as well as Stalinism, extreme Islamism and identity to argue that 'symbolic collectivisation - or as one might phrase it, the predominance of thinking and acting in categorical terms - is a de-individuating and hence dehumanising practice with potentially tragic effects' (Rapport 2012,8 ). For many others who belong to minorities, such as myself, identifying in categorical terms is a form of empowerment; a way to say: I have social connections outside of this heteronormative and patriarchal existence. 'Look, I exist and I am not alone.

Moreover, his third claim of the book, that 'one may conceive of a set of norms which serves as a universal ethic of polite human interaction: "cosmopolitan politesse"' (Rapport 2012, 2) sounds like a rallying call for respectability politics, the kind of political position that tells women, usually feminists, to play nice and be kind, 'don't be so angry', if we speak to each other nicely, only then will progress be made. I continue my discussion of this notion in the next section.

POLITESSE DOES NOT NATURALLY OCCUR TO THOSE WITHOUT PRIVILEGE

Rapport devotes chapter three of his book to discussing 'civility as politesse' (Rapport 2012,174) which is the notion that we can raise politeness to a virtue 
and one that people should and must abide by. He says, 'the superficial polite engagement with an other is, I shall suggest, a means to interact with Anyone' (Rapport 2012, 174). However, as I have argued, even a polite distance seems difficult to occupy for some people, let alone a superficial politeness. He qualifies his position by saying that his version of cosmopolitanism is one in which 'one may conceive of a set of norms which serves as a universal ethic of polite human interaction' (Rapport 2012, 2). Politesse, he says, 'is the term I employ to describe kinds of cosmopolitan "good manners," compromising both a polite style of general public exchange and an ethic of individual dignity and freedom' (Rapport 2012, 174). Yet, only particular kinds of individuals are offered dignity and freedom and the right to public exchange. For example, I think particularly of all the women on the internet who are threatened with murder, rape and called every conceivable insult when they express an opinion that challenges oppression, patriarchy or male privilege. I conjure up public intellectuals or commentators like Anita Sarkeesian and Clementine Ford. Sarkeesian created a YouTube channel called Feminist Frequency critiquing the once overwhelmingly male domain of gaming and was the reason behind the \#gamergate phenomenon which exploded the conversation around sexism in gaming began. Ford, explores issues around gender, and sexism in Australian life. Both have been threatened with rape, bodily harm and murder by men who do not like what they have to say on the subject of male privilege and who do not express a politesse or embody what Rapport calls 'exemplars of humanity' (Rapport $2012,174)$. These women have considerable cultural capital and power; imagine those who do not, and how vulnerable the less powerful are to attacks and harassment both online and off. Rapport does explain though that, regular exchanges between people should not be conflated with common understandings or a coming together of individuals on anything but a formal superficial level (Rapport 2012, 182). He says, 'what is important for politesse - that which makes its superficialism into a virtue - is the instituting and valuing of a form of life, a surface of mannered routine exchange, beneath which all manner of individual and idiosyncratic opinion - on identity, on religiosity, on fashion, on football - might flourish' (Rapport 2012, 177). My critique of politesse is that it is a utopian idea that does not describe or account for everyday lived reality of many people, in this instance, for women's lived realities.

As we know from statistics across the world regarding increasing pay gaps, in Australia the gender pay gap for fulltime employees sits at 17.7 per cent (Australian Bureau of Statistics 2015), on average across the EU in 2005 it was 15 per cent and in central Asia it was 40 per cent (United Nations Economic Commission for Europe 2007). In America in 2014, women working full time in the United States typically were paid 79 per cent of what men were paid 
which is a gap of 21 per cent (Hill 2016). Globally, the gender pay gap has not changed between 2006 and 2015 (World Economic Forum 2015). As a result, playing nice only serves to silence and pay literal lip service to the dominant hegemony. Politesse is not, as Rapport argues 'naturally occurring' (Rapport 2012,175 ) for any but the most privileged. Women have had to fight for their most basic rights such as the right to vote, and continue to fight to end the statistic that makes intimate partner violence the leading cause of death for women aged 15-40 in Australia (VicHealth 2004 ), and many countries across the world. If people who purport to love their partners murder them, what hope do we have regarding the politeness of strangers?

Rapport claims that we can all communicate with one another because 'Anyone is given an equal place as partner to public interaction on the basis of a democratic view of membership, and the truth surrounding individual world views - 'how Anyone is interpreting self and world - as well as the distaste this diversity is likely to occasion, are kept from conscious public concern' (Rapport 2012, 183). Yet again recent statistics regarding street harassment found 96 per cent of women internationally (Fileborn 2013) have experienced some form of physical or verbal street harassment. This too highlights how only some people are in the privileged position to keep things from their conscious concern.

Rapport asserts, 'there is a viable cosmopolitan project for anthropology involves carrying forward a Classical and Enlightenment tradition of thought' (Rapport 2012, 14). However, my research on the limits of rationality and modern rational identity creation, argues that this tradition makes masculinist versions of us all. Specifically, it creates subject positions where men are represented as subjects with a Self but with no body to call a Self. Conversely, women are represented as the Other with a body but no mind to call a Self, so that we are both left half formed in theory (Lewis 2011). The production of knowledge and the Enlightenment tradition of thought presents a one-dimensional teaching of how to be in the world. It affixes us to an objectifying mind gaze that is needed to think rationally as western subjects and shrivels our abilities to use our emotions and bodies as sites of knowing. We get stuck in the mind = man and body = woman ideological arrangement that is still echoed in our Cartesian way of being in the world. In Rapport's instance though, men become symbolic of the mind and the body or being embodied.

This recognition of historical self making bound to dualistic ideas of personhood does not discount identities that exist outside the binary or alongside it as I have already discussed. As we know from Janet Wolff's work, identity is 'always gendered identity, political and other ideologies operate through notions 
of gender difference, and discursive oppositions are also complexly interwoven with meanings and discourses of gender' (cited in Stivens 2000, 10). As Shmuel Eisenstadt says 'multiple modernities are at stake' (cited in Braidotti 2008, 10) and not just a western enlightenment style of modernity. In a post 9/11 world order Braidotti argues that sexual difference has returned to the world stage in a fundamentalist and reactionary version, re-instating a worldview based on colonial lines of demarcation (Braidotti 2008). It positions women's bodies as markers of authentic cultural and ethnic identity. So how can cosmopolitanism which is tied up in an androcentric worldview and rests on calling up a Classical and Enlightenment tradition of thought' (Rapport 2012,14) possibly even adequately grapple with, let alone, as I have discussed, make space for gender and the complexities of woman's place in the equation? Even if it did, it would leave the unpacking to women and individuals who embody womanhood which is not what a feminist political practice needs or indeed requires. Theodossopoulos admits, cosmopolitanism, like globalisation, can be regarded as a form of domination (Theodossopoulos 2010). The absence of any reference to women and cosmopolitanism in Rapport's book makes it all the more dominating. Feminist women are not even given the recognition that they speak on the subject too which is a carry over from past anthropological volumes such as James Clifford and George Marcus' (1986) classic, Writing Culture that also excluded specifically feminist voices. In his defense at the time, Clifford said, the 'exclusion of feminist perspectives from the present volume limits and focuses its discursive standpoint' (Clifford 1986, 17). He also said, 'feminism had not contributed much to the theoretical analysis of ethnographies as text' (Clifford 1986, 17) which is eerily echoed by Rapport's exclusion. It took Behar and Gordon's (1995) collection Women Writing Culture to point out that Barbara A. Babcock was committed to seeing discourse and knowledge as situated and perspectivist (Babcock 1995, 105), as was Ruth Benedict's 1935 ethnography Zuni Mythology and many other works after this. Recognition of one's ability to tell only partial truths was also posthumously attributed to Margaret Mead by Nancy C. Lutkenhaus (1995) in her contribution to Behar and Gordon's (1995) collection, who said, Margaret Mead went to lengths to explain the significance of the idiom, 'from where I sit' (Lutkenhaus 1995, 192) in her 1949 ethnography Male and Female. Although as Lutkenhaus notes she was not so progressive that she included her racial and class position in her reflections on her own situated truth construction (Lutkenhaus 1995, 192). In a fascinating study by Judith Newton and Judith Stacey (1995) on prominent male cultural critics including an interrogation of their reasons for not openly speaking about feminism or feminist theory in their work, they found that the answer was not a simple rejection of the ideas or importance of such work, but an inability to know how to speak about it, to it, or for it. There was even a fear of speaking 
to it (Newton and Stacey 1995, 298). According to Bolles (2001, 30), African American anthropologist Zora Neale Hurston used a reflexive ethnographic method alongside a mixed method of narrative fiction and social scientific analysis decades before it was celebrated by post modernists and Clifford and Marcus' (1986) Writing Culture.

Having laid out the philosophical arguments for my rejection of 'Anyone' as an anthropological subject, I now turn to a short case study of the dangerous limitations of the notion of politesse as an ethical orientation towards others.

THE PEOPLE VERSUS PICK-UP ARTISTS: A CASE STUDY

This essay argues that we do not live in the democratic world that Rapport's reflections on cosmopolitan encounters supposes. Instead, the invitation of politesse for 'Anyone to fulfil him or herself' (Rapport 2012, 194) can have dire consequences. As I will illustrate below, there is nothing polite about Pick Up Artists (PUAs) such as Julien Blanc and their techniques. They do have a set of norms, a universal one at that, but obviously not the kind of norms that Rapport is advocating. The women constructed by these pick up artists in their published literature and 'self-help groups' are most definitely not partners to public interaction in Rapport's notion of cosmopolitan politesse. Instead, they are made objects to be dominated.

Julien Blanc is a minor media celebrity from a company called Real Social Dynamics who advocates forms of picking up women that include choking, manipulation and psychological abuse lifted from a chart used by domestic violence services for women to identify when they are being abused (Kent 2016). He tells attendees at his seminars, 'If you're a white male, you can do what you want' (Kent 2016). His YouTube videos show him grabbing women's heads and pushing them towards his crotch as examples of his everyday practice, in this instance, as an American traveller in Japan. The company Real Social Dynamics is a group of men known as 'Pick-Up Artists' (Purtill 2016) who run seminars on how to intimidate women into submission using aggressive techniques and psychological tricks. These techniques were explored in detail in the best selling book The Game (Strauss 2005). Strauss details eleven steps in his book with the disclaimer 'don't hate the player, hate the game' (Strauss 2005). Chapters or what he calls 'steps' one to six are: (original capitals retained)

STEP 1

SELECT A TARGET 
STEP 2

APPROACH AND OPEN

STEP 3

DEMONSTRATE VALUE

STEP 4

DISARM THE OBSTACLES

STEP 5

ISOLATE THE TARGET

STEP 6

CREATE AN EMOTIONAL CONNECTION

Steps 10 and 11 are also notable:

BLAST LAST-MINUTE RESISTANCE; MANAGE EXPECTATIONS

Even from the contents page titles it becomes clear to the reader that women are constructed as 'things' or objects to manipulate rather than as people. Strauss followed around 'Mystery', the alias for the person whom he calls 'the greatest pickup artist in the world', and from whom he learnt the craft, if you can really call it crafty. His book is based on the The How-to-Lay-Girls Guide which was the 'collected wisdom of dozens of pickup artists who have been exchanging their knowledge in newsgroups for nearly a decade, secretly working to turn the art of seduction into an exact science' (cited in Strauss 2005, 9). In other words, to make self declared, unattractive, balding guys like Style into seduction machines able to woo the most beautiful women in the world, 'in Los Angeles, New York, Montreal, London, Melbourne, Belgrade, Odessa, and beyond' (Strauss 2005, 7)... to become what every woman wants - not what she says she wants, but what she really wants, deep inside, beyond her social programming, where her fantasies and daydreams lie (Strauss 2005, 12).

In December 2014 Julien Blanc of Real Social Dynamics was deported by the Australian immigration minister for promoting violence against women after an international social media campaign with the hashtag \#TakeDownJulienBlanc went viral (Gibson 2014). The campaign was started in the United States by American Chinese woman, Jennifer Li, after she saw the aforementioned YouTube video of him physically grabbing women in Japan as examples of his 'techniques.' Li said, 'by perpetuating the idea that Asian women are a "free for 
all" for predatory men, he is encouraging other pathetic men to abuse them. After listening to Blanc's "teachings", his followers think it's okay to have yellow fever, or to act out their sick power fantasies on Asian women' (Li 2014).

Blanc's colleague, Jeff Allen, who was due to present his own version of PUA seminars this year (2016) left Australia before his visa could be officially cancelled after a similar international social media campaign calling hotels and conference centres hosting them and their events, as well as the Australian Government, to act and deny them entry. The campaigns against these two men show the importance of emancipatory political practice in actual practice not just theory. However, in fairness to my own claimsmaking, it has been claimed that them getting banned from entering various countries was actually an orchestrated publicity stunt. Another high profile PUA claimed that Allen always intended to be deported, and that his Australia tour was an exercise in gaining further notoriety and hence publicity (Purtill 2016). In retrospect however this seems rather doubtful because his personal appearances garnered him thousands of dollars. At this point, I move on in the next section of this essay to consider if the answer to these gendered dilemmas with cosmopolitan theory is to engage in a feminist version of it.

\section{COULD A FEMINIST COSMOPOLITAN THEORY BE THE ANSWER?}

Reilly identifies the global women's human rights movement as exemplifying emancipatory political practice in its refusal to accept discriminatory practices (Reilly 2007, 183). It entails, she says, 'a critical engagement with international human rights law; a global feminist consciousness that contests patriarchal, capitalist, and racist power dynamics in a context of neoliberal globalisation' (Reilly 2007, 180). Importantly, it 'recognises the intersectionality of forms of oppression' and rests on 'collaborative transnational strategizing on concrete issues; and the utilization of global forums as sites of cosmopolitan solidarity and citizen action' (Reilly 2007, 180). This can clearly be seen in the solidarity and action moved against PUAs. It follows then that a 'cosmopolitan feminism does not assume that women are united by a common gender identity or common experience of patriarchal oppression across regions and other boundaries' (Reilly 2007, 182).

In essence Reilly is arguing for a feminist cosmopolitanism rather than global feminism or feminism as an ideological position. Her purpose, in my view, is to prize open the category of cosmopolitanism and the very gendered manner in which it often neglects to reflect on its own ideological underpinnings. Reilly offers five mutually constitutive moments that need to be taken together 
in order to understand cosmopolitan feminism as a transformative political framework (Reilly 2007, 184).

These are:

- A critical engagement with public international law,

- A global feminist consciousness that challenges the systematic interplay of patriarchal, capitalist, and racist power relations,

- Recognition of intersectionality and a commitment to cross-boundaries dialogue, networking and social criticism,

- The development of collaborative advocacy strategies around concrete issues, and

- The utilisation of global forums as sites of cosmopolitan solidarity and citizenship (Reilly 2007, 184).

Emancipatory political practice then, is what Reilly (2007) defines as a result of the practice of a cosmopolitan feminism. However, what I think people rose up for in response to Julien Blanc, was the category of 'woman', not a shared recognition of the feminist cosmopolitanism of which she is an advocate. The recognition of the category of woman or women in general as subjects has always been a feminist issue and already engages with the five moments that Reilly (2007) addresses above. One exception is perhaps the last point, which refers explicitly to cosmopolitan solidarity and is not understood outside largely academic circles. A counter to my own assertion and drawn to my attention by an anonymous reviewer is Mica Nava's (2007) Visceral Cosmopolitanism. Nava argues that cosmopolitanism has been a popularly understood concept in London since 1909 when it was conjured up by Gordon Selfridge, owner of the 'iconic' Selfridges department store in his weekly syndicated newspaper columns. A search in Australia's The Age newspaper, Victoria's independent newspaper, for the term cosmopolitan returns 1,140 results but of the first ten of these only one actually refers to the academic definition of cosmopolitanism when referring to 'Thae Yong Ho, a cosmopolitan career diplomat', another refers to the city of Melbourne as 'an inclusive, cosmopolitan and exciting hub where adults are treated as such yet can remain young at heart and party on their own terms' (Squires 2016), another to migration, 'the migration of Matisse to Sydney Harbour: this was the kind of provocative, cosmopolitan, "big statement" art that defined a new, post-Menzies Australia' (McAuliffe 2016), and another about loving home in the love the cosmopolitan mix of vibrant young people in my Tower of Babel' (Blashki Pohl 2016) context. For the purposes of my own argument however it is important to note that the remainder are property listings, reference to a cosmopolitan soccer league and Women's 
magazine, Cosmopolitanism. It is true, as Nava $(2007,12)$ argues that there is a kind cosmopolitanism that takes place at home, in the family, in the neighbourhood, in the interior territories of the mind and body, such as in the case study she uses of the romance between Dodi and the late Diana Princess of Wales. She says, it suggests a structure of feeling that exists independently of travel to foreign countries or knowledge of foreign languages and offers the allure of difference (Nava 2007, 12). Such narratives do indicate that 'women are addressed as subjects' (Nava 2007, 6), but from the weight of my previous arguments it is equally true that women are also excluded as subjects.

Global forums like the 1993 Vienna Declaration that recognised violence against women as a violation of human rights which Reilly (2007) references, have existed without the need for a specifically cosmopolitan feminism. Cosmopolitan feminism, she says, 'rejects the Western-centric, falsely universalised, narrowly defined understandings of human rights' and 'retains a commitment to critically reinterpreted universal human rights in the context of democratically grounded, emancipatory political projects' (Reilly 2007,181 ). So too do many forms of feminism, especially many anthropologists who are feminists and who use feminism as a place of ideological critique and practice. The idea of cosmopolitan feminism is appealing, but why create a new form of feminism when the current one is just as effective and has more scope to be understood both inside and outside academia? Why retain cosmopolitanism as a project when we could just as easily, without the cultural baggage drag of cosmopolitanism and its history, turn to human rights based feminism as many authors (Stivens 2000), have done and/or to feminism that is grounded in intersectional understandings of power. At their essence, rights based feminisms are about recognising female personhood in a world order that still treats women as second class citizens no matter the prevailing rules of law, which I think underpins Reilly's (2007) push for a cosmopolitan feminism. Also true is that Rapport's (2012) version of cosmopolitanism is an androgynous one at best, that actually excludes by omission, so why force open a cloaked position with feminist cosmopolitanism when you could use feminism or a human rights based feminism just as, if not, more effectively?

Interestingly, Rapport does not mention political practice at all in his work because his focus is on the embodied, phenomenologically experienced individual. He says 'cosmopolitan norms endowed individuals not states or communities with rights and claims' (Rapport 2012, 44). This is a highly problematic reading of power in the content of PUAs and the kind of power they exercise as individuals, which is greater than individual women wield, but not greater than the collective, transnational political practice of women centred 
networks and their strategic and effective use of rights and claims on behalf of women to deport PUAs. What Rapport does say about engaging people on a global scale, is that 'cosmopolitan politesse, is conceived of as moral means to engage with Anyone on a potential global scale' (Rapport 2012, 185). In the instance of PUAs, only other PUAs are considered equal 'Anyones'-women as I have discussed-are objects or things to be conquered and manipulated. Women have no place to 'become' or be 'appreciated' in this context (Rapport 2012, 185) of unequal power relations and patriarchal positioning. Rapport believes, speaking from his position of privilege I suggest, that 'politesse effects an "organisation of diversity", aggregating individuals and their communities, traditions, localities, professions and occupations into a social whole' (Rapport 2012, 186). Perhaps this is true for him and people who embody an 'Anyone' that is close to his own individual being in the world, but it is not mine, nor most women's, nor the women who are subject to PUAs grotesque 'techniques'. The social whole that I see and that most women, men and people experience, is one built on inequalities, not a horizontal, equitable 'organisation of diversity'. Cosmopolitanism feminism on the other hand, contests relativist and communitarian claims over individually held human rights when they are used to conceal violations against women in the name of the cultural or religious integrity of the community (Okin 1999). Contrary to this lived reality though, Rapport says, 'no particular identity can be imprisoning, or a site of irremovable discrimination, for Anyone as a universal human being undercuts any momentary manifestation' (Geller and Stockett 2006, 12). Again, this kind of comment sounds like the voice and reason of privilege speaking, as for many people irremovable discrimination is their daily experience. Identity, chosen or socially assigned, can be a very real prison. Donald Trump, now president of America, reminded us of this after his comments about women that as a white man who is a 'star', he can 'grab them by the pussy' and 'just start kissing them' (CNN 2016).

Next I will highlight why I think cosmopolitanism has a cultural baggage drag and why it is important to move away from using it as a position from which to argue.

REFLEXIVE SELVES, GLASS CEILINGS AND HISTORICAL POWER STRUCTURES

As Mette Louise Berg argues, a cosmopolitan anthropology needs 'to engage in a reflexive practice on its own knowledge production' (Berg 2010, 436). What she is pointing at is Anthropology's very white, western, heterosexual, ablebodied, scientifically rational, male perspective that was the beginning of the discipline and remains, sadly, the face of it today. In her article, 'On the social 
ground beneath our feet: for a cosmopolitan anthropology', she argues that the knowledge that academia produces is situated within historical power structures (Berg 2010, 433). These are the same power structures that create the current conditions in which sexism, racism, and various forms of Othering are produced and reproduced in the world at large. The Self then, in and outside academia, remains largely, a white, male who is usually heterosexual, Michel Foucault is a notable exception as is Judith Butler. As a result, the knowledge that is then produced and published, predominantly serves the interests of white men who dominate Anthropology.

As Jean-Francois Lyotard argued, 'it may be that you are forced to be a man from the moment that you write' (Lyotard 1989, 91) because language itself is a masculinist creation. What I am trying to get at, is that it is no surprise that Rapport's 'Anyone' ends up being representative of a white heterosexual man, as it is this subject position that still dominates life at large and academia. This is not a new a new claim but it highlights just how little progress we have made in terms of ideology and the exclusion or silencing of the female subject. For example, in the 1974 collection Woman, Culture, Society (Rosaldo and Lamphere) it was revolutionary to argue that women's lives were important fields of anthropological study. Seven years later we moved on from needing to argue that women were important to highlighting the lack of women in academia who were any colour but white with the 1981 collection This Bridge Called my Back: Writings By Radical Women of Colour (Moraga and Anzaldua 1983). Feminist anthropological collections like Geller and Stockett's (2016) Feminist Anthropology: Past, Present, Future state that the intersection of power, difference and identity is the place at which many feminist anthropologists are now situating their research (Geller and Stockett 2006, 12). Thus, they are explicitly recognising the power differentials inherent in the construction of knowledge and being loud about it, at least the ones in that particular collection. Yet we find ourselves with another book, 30 years after Clifford and Marcus' (1986) Writing Culture was critiqued for excluding women, doing exactly the same thing.

Ruth Behar argues of women writers that, 'even when they are supposed to be addressing women, [they] write for men; or at least they write with the haunting sense of being overheard by men, and certainly with the inescapable knowledge of having already been defined in men's words' (Behar 1995, 5-6). So even while this knowledge may lay claim to being inclusive, often, as is the case of cosmopolitanism as a grand narrative, and in particular Rapport's version of it, it is not inclusive. 
The university as an institution is bound up in power and hierarchy and social relations that produce and reproduce inequality despite also being the site of radical critiques of these power and social relations. Berg (2010) uses Bourdieu to remind us of the 'charismatic representation that cultural producers have of themselves and their propensity to see themselves as free of all cultural determinations' (Bourdieu cited in Berg 2003, 283). In other words, what Berg (2010) is pointing at is what we would call in current day parlance, the invisibility of privilege. Or just plain privilege. This privilege creates a concept within which a cosmopolitan 'Anyone' can exist.

RIGHTS BASED FEMINISMS ARE A BETTER UNIFYING PRINCIPLE THAN COSMOPOLITANISM

Now that I have highlighted the shortcomings of cosmopolitan theories, I am going to explore a more helpful alternative. I reiterate that 'feminist critiques of western political thought have pointed to the masculinism of the modernity/ post-modernity and globalization debates [and] ...in systematically excluding the female, these debates assumed that the modern, autonomous, individual subject is a man' (Felski 1995; Hilsdon et al. 2000; Stivens 2000). This tradition continues in discussions around Cosmopolitanism as I have been arguing. So I offer here the well explored position of human rights feminism as an alternate and more successful way to unify diverse subject positions. Chandra Mohanty (2003) explains that a coherent Third World feminist standpoint can be identified, despite the multiplicity of identities and locations occupied by Third World women, and it speaks and operates in terms of human rights as being women's rights. Just like Charlotte Bunch's notion of a global feminism in her article 'Women's rights as human rights' (Bunch 1990), and Stiven's argument that 'enlarged and globalised spheres of feminist action around women's human rights can usefully be termed a global feminist public' (Stivens 2000 , 10). This theoretical positioning is perfectly executed in practice in my initial example of Real Social Dynamics propagators and the backlash against them in the name of standing up for women's rights and the right to be free of violence and harassment.

However, Lila Abu-Lughod (2002) suggests this call for a universal like human rights reinforces an ideological position of the west saving the rest with their rights rhetoric. She says that this positioning negates the possibility or paths toward change that are not necessarily premised around a desire for freedom or liberation in a historically western sense. She says that perhaps we need to ask 'might other desires be more meaningful for different groups of people?' (Abu-Lughod 2002, 789). According to Rosalind Petchesky though, to dis- 
miss particular concepts as being 'a "Western" import makes little sense unless we are ready to repudiate "democracy", "freedom", "national sovereignty" and "development" for the same reason' (Petchesky 2003, 3) which perhaps AbuLughod would champion.

Sarah Amsler (2014) says that the times call for a new project of radical feminist re-imagination, not only of our contemporary problems but of possible futures as well'. They also call for the collective cultivation of concrete political strategies to defend both hard-won rights of gender equality and more fragile progress in democratising critical, anti-patriarchal forms of thought and ways of life. Feminism as an ideology is always evolving and its position has always been the somewhat ironically radical notion that all people are equal and deserve to be treated as such. When not even one feminist or woman centred cosmopolitanism is included in a book by a renowned Anthropologist there is much more fighting to be done. The fact that he accounted for twenty-two varieties at a moment in history when there are many feminist and female centred perspectives currently being explored across the world, is a product of a culture that overlooks women's voices, experiences and perspectives no matter how loud or prolific they may be. This is the very definition of sexism.

\section{CULTURAL SECRETS}

Finally, I want to draw in Michael Herzfeld's concept of cultural intimacy, the recognition of those aspects of cultural identity that are considered a source of external embarrassment but that nevertheless provide insiders with their assurance of common sociality (Herzfeld 2005, 3). Recognising human beings as all connected by humanity yet distinctly individual, as cosmopolitanism does, is beautiful in theory but in practice, to achieve it, we have a long, long way to go. We would like it if we could all be cosmopolitan citizens of the world, that is our cultural secret as anthropologists, but practice tells us otherwise and while a global cosmopolitanism is a worthy aspiration, it is still a transcendent hope, even if it is bound by immanent ideological underpinnings. It is cultural intimacy, 'the familiarity with the bases of power that may at one moment assure the disenfranchised a degree of creative reverence and at the next reinforce the effectiveness of intimidation' (Herzfeld 2005, 3), that I am arguing allows for a cosmopolitan project to flourish. In fact, Rapport recognises the critique of cosmopolitanism being a 'mask for white male privilege' (Rapport 2012, 35). Yet does little to dispel the critique, other than briefly mention it as Immanuel Kant's original ideal cosmopolite. Kant's cosmopolitan ideal is, I suggest, a current day manifestation of the globe trotting masculinist. 
While Herzfeld talks about the nation-state primarily and the voices that contribute to what is often essentialised as the homogenous category 'the state' (Herzfeld 2005, 1), the same argument can easily be extended to critique the universalising of cosmopolitanism theory. That is, there is a cultural intimacy in forwarding the concept of a cosmopolitan Anyone in that it can in theory encompass literally any body, any where. But the material truth of the matter is that on closer inspection and in lived reality, only certain bodies come to be heard and seen as Anyone because they exist in a world order bound to social categorisation, an ideological framework that is still needed in a world society where the Self is still male and the Other is very definitely not Anyone but everyone else. Recognising that we have a cultural intimacy of our own to defend is important (Herzfeld 2005, 223). Indeed, comparison is meaningless if we do not subject our own assumptions to the same analytic questioning (Herzfeld 2005, 223) not only to the societies we study as Berg (2010) and many others have highlighted, but also to our own discipline. There is a 'gendered effect in disembodying representations and understandings of academic work' (Mills and Berg 2010) as it happens but also in what it produces.

\section{CONCLUSION}

At a moment in history where women and men are battling gender inequality, toxic masculinity, ingrained gender roles and so much more, we cannot back step into ideological arrangements that again hoist Anyone as a faceless subject into the forefront of theoretical analysis and practice. Cosmopolitanism has this as its aim and tacking feminism onto it does feminism a disservice and I think, turns a blind eye to these historical struggles to get away from the invisible cosmopolitan androcentric subject. Utilising a human rights framework to talk about global social movements is more productive in that it is easily recognised as such. In the case of pick up artists and the revolt against them, people were and are standing up for the rights of women to live free from discrimination and the threat of violence, not the globe trotting cosmopolite who sounds more like the face of Real Social Dynamics and uses their global mobility to spread their message. Emancipatory political practice lives beyond nations in digital worlds that seep out into everyday social resistance where the category of woman is needed and pointed to as a form of both potential oppression and a symbol of emancipation. Cultural intimacy or not, smuggling peripheral ideological positions like cosmopolitan feminism in is not necessary when we already have a global human rights movement that is standing up and for women. And we have feminism. Why look elsewhere?

After all, it is always a very predictable 'someone' who ends up in the borders of 
history and what Anzaluda (1987) called the Borderlands. As Nava says of Edward Said's thesis about orientalism, in which imagined orients contribute to the management, exploitation and domination of 'others' and the 'East' (Nava $2007,6)$ so too does the imagined 'Anyone' contribute to the management, exploitation and domination of 'others.' Especially when the 'other', is in fact, half of the population named Woman.

NOTES

1 Brigitte Lewis has a $\mathrm{PhD}$ from the University of Melbourne on rational female identity creation in 21st century Australia. She works as a Research Officer and Web Developer for the Gendered Violence and Abuse Research Alliance (GeVARA) at RMIT in Melbourne, Australia. Follow her @briglewis.

Email: brigitte.lewis@rmit.edu.au

\section{REFERENCES}

Abu-Lughod, Lila. 2002. 'Do Muslim Women Really Need Saving? Anthropological Reflections on Cultural Relativism and Its Others'. American Anthropologist 104 (3): 783-90.

Amsler, Sarah. 2014. 'For Feminist Consciousness in the Academy'. Politics and Culture, Materialist Feminisms Against Neoliberalism. https://politicsandculture.org/2014/o3/o9/for-feminist-consciousness-in-the-academy/.

Anzaldua, Gloria. 1987. Borderlands/La Frontera: The New Mestiza. San Francisco: Aunt Lute Books.

Australian Bureau of Statistics. 2015. In Average Weekly Earnings, Australia, Nov 2015. Canberra.

Babcock, Barbara A. 1995. 'Not in the Absolute Singular: Re-reading Ruth Benedict'. In Women Writing Culture, edited by Ruth Behar and Deborah A. Gordon, 104-30. Berkeley: University of California Press.

Behar, Ruth. 1995. 'Introduction: Out of Exile'. In Women Writing Culture, edited by Ruth Behar and Deborah A. Gordon, 1- 32. Berkeley: University of California Press.

Behar, Ruth, and Deborah A. Gordon, eds. 1995. Women Writing Culture. Berkeley: University of California Press. 
Benedict, Ruth. 1935. Zuni Mythology. Columbia: Columbia University Press.

Berg, Mette Louise. 2010. 'On the Social Ground Beneath our Feet: For a Cosmopolitan Anthropology'. Social Anthropology/Anthropologie Sociale 18 (4):433-440.

Bolles, Lynn. 2013. 'Telling the Story Straight: Black Feminist Intellectual Thought in Anthropology'. Transforming Anthropology (1): 57.

Braidotti, Rosi. 2008. 'In Spite of the Times: The Postsecular Turn in Feminism. Theory, Culture \& Society 25 (6):1-24. doi: http://dx.doi.org/10.1177/ 0263276408095542 .

Bunch, Charlotte. 1990. 'Women's Rights as Human Rights: Toward a Re-Vision of Human Rights. Human Rights Quarterly 12 (4): 486-498.

Clifford, James. 1986. 'Introduction: Partial Truths'. In Writing Culture: The Poetics and Politics of Ethnography, edited by James Clifford and George E. Marcus, 1-26. Berkeley: University of California Press.

Clifford, James, and George E. Marcus, eds. 1986. Writing Culture: The Poetics and Politics of Ethnography. Berkeley: University of California Press.

CNN. 2016. Donald Trump: 'Grab them by the pussy' original. Retrieved 11 November 2016 from https://www.youtube.com/watch?v=l8UoIaMsRf4.

Fileborn, Bianca. 2013. 'Conceptual Understandings and Prevalence of Sexual Harassment and Street Harassment'. In ACSSA Resource Sheet No. 6. Melbourne: Australian Institute of Family Studies.

Geller, Pamela L., and Miranda K Stockett, eds. 2006. Feminist Anthropology: Past, Present, and Future. Philadelphia: University of Pennsylvania Press.

Gibson, Megan. 2014. 'Is This the Most Hated Man in the World?' Accessed 4 September 2016, http://time.com/3578387/julien-blanc-feminism-real-socialdynamics/.

Herzfeld, Michael. 2005. Cultural Intimacy : Social Poetics in the Nation-State. 2nd ed. New York: Routledge.

Hill, Catherine. 2016. 'The Simple Truth about the Gender Pay Gap'. American Association of University Women. Accessed 7th November 2016, http://www. 
aauw.org/research/the-simple-truth-about-the-gender-pay-gap/.

Hilsdon, Anne-Marie, Maila Stivens, Martha Macintyre and Vera Mackie, eds. 200o. Human Rights and Gender Politics: Asia-Pacific Perspectives. London: Routledge.

Holloway, Kali. 2015. 'Miley Cyrus Is Not Alone: 9 Other Stars Making Gender Fluidity Mainstream.' Alternet. Accessed 7th November 2016, http://www. alternet.org/gender/miley-cyrus-not-alone-9-other-stars-making-genderfluidity-mainstream.

Kent, Lucinda. 2016. 'Why is pick-up artist Julien Blanc the "most hated man in the world"?' sвs, Accessed, 18th January, http://www.sbs.com.au/topics/life/ article/2016/o1/18/why-pick-artist-julien-blanc-most-hated-man-world.

Lewin, Ellen. 2006. 'Introduction: Feminist Anthropology: A Reader'. In Feminist Anthropology: A Reader, edited by Ellen Lewin, 1-38. Malden: Blackwell Publishing

Lewis, Brigitte. 2011. Epistemological Blind Spots and the Story of I: Returning the Vulnerable $i$ to the Rational I. Doctor of Philosophy (Sociology), University of Melbourne.

Li, Jennifer. 2014. 'Julien Blanc is a Racist Sexual Predator Teaching Men to Prey on Women Like Me-And He Must be Stopped'. Independent Accessed 5 September 2016, http://www.independent.co.uk/voices/comment/julienblanc-is-a-racist-sexual-predator-teaching-men-to-prey-on-women-likeme-he-must-be-stopped-9843939.html.

Lutkenhaus, Nancy C. 1995, 'Margaret Mead and the "Rustling-of-the-wind-inthe-palm-trees-school" of Ethnographic Writing'. In Women Writing Culture, edited by Ruth Behar and Deborah A. Gordon, 186-206. Berkeley: University of California Press.

Lyotard, Jean-Francois. 1989. 'One of the Things at Stake in Women's Struggles'. In The Lyotard Reader, edited by Andrew Benjamin, 111-121. Oxford: Basil Blackwell.

McAuliffe, Chris. 2016. 'Brett Whiteley Review: Ashleigh Wilson Gives the Artist the Life he Deserves. The Age. Accessed 23 August 2016, http://www.smh. com.au/entertainment/books/brett-whiteley-review-ashleigh-wilson-gives- 
the-artist-the-life-he-deserves-20160804-gqkt8g.html.

Mead, Margaret. 1949. Male and Female. New York: Harper Perennial.

Mills, David and Berg, Mette Louise. 2010. 'Gender, Disembodiment and Vocation: Exploring the Unmentionables of British Academic Life'. Critique of Anthropology 30 (4):331-53.

Mohanty, Chandra Talpade. 2003. Feminism Without Borders. Durham: Duke University Press.

Moraga, Cherrie, and Gloria Anzaldua, eds. 1983. This Bridge Called My Back: Writings By Radical Women of Colour and ed. New York: Kitchen Table: Women of Colur Press.

Mosko, Mark S. 2015. 'Unbecoming Individuals'. Des individus inconvenants: La divisibilité de la personne Chrétienne. 5(1):361.

Nava, Mica. 2007. Visceral Cosmopolitanism: Gender, Culture and the Normalisation of Difference. Oxford: Berg.

Newton, Judith and Stacey, Judith. 1995. 'Ms. Representations: Reflections on Studying Academic Men'. In Women Writing Culture, edited by Ruth Behar and Deborah A. Gordon, 287-305. Berkeley: University of California Press.

Okin, Susan.1999. Is Multiculturalism Bad for Women? Princeton: Princeton University Press.

Petchesky, Rosalind. 2003.Global Prescriptions: Gendering Health and Human Rights. London: Zed Books.

Purtill, James. 2016. 'Real Social Dynamics and the Evolution of the Pick-up Industry'. Accessed 5 September 2016, http://www.abc.net.au/triplej/programs/hack/real-social-dynamics-and-the-evolution-of-the-pick-up-industry/7099368.

Rapport, Nigel. 2012. Anyone: The Cosmopolitan Subject of Anthropology. New York: Berghan.

Reilly, Niamh. 2007. 'Cosmopolitan Feminism and Human Rights'. Hypatia $22(4): 180-198$. 
Roman-Odio, Clara, and Marta Sierra, eds. 2011. Transnational Borderlands in Women's Global Networks. New York: Palgrave Macmillan.

Rosaldo, Michelle Z., and Louise Lamphere, eds. 1974. Woman, Culture, Society. California: Stanford University Press.

Schiller, Nina Glick, and Andrew Irving. 2014. Whose Cosmopolitanism?: Critical Perspectives, Relationalities and Discontents. New York: Berghahn Books.

Squires, Wendy. 2016. One of These Cities Treats Adults as Grown-ups, The Other Doesn't. Accessed 23 August 2016, http://www.smh.com.au/comment/a-tripto-sydney-isnt-nearly-as-much-fun-as-it-used-to-be-2016o804-gql5m4. html.

Strathern, Marilyn. 1988. The Gender of the Gift. California: University of California Press.

Stivens, Maila. 200o. 'Introduction: Gender Politics and the Reimagining of $\mathrm{Hu}-$ man Rights in the Asia-Pacific.' In Human Rights and Gender Politics: AsiaPacific Perspectives, edited by Anne-Marie Hilsdon, Maila Stivens, Martha Macintyre and Vera Mackie, 1-36. London: Routledge.

Strauss, Neil. 2005. The Game. New York: Regan Books.

Theodossopoulos, Dimitrios. 2010. 'Introduction: United in Discontent'. In United in Discontent: Local Responses to Cosmopolitanism and Globalization, edited by Dimitrios Theodossopoulos and Elisabeth Kirtsoglou, 1-19. New York: Berghahn Books.

Theodossopoulos, Dimitrios, and Elisabeth Kirtsoglou, eds. 2010. United in Discontent : Local Responses to Cosmopolitanism and Globalization. New York: Berghahn Books.

The World Bank Group. 2016. 'Population, Female'. The World Bank. Accessed, 6th November 2016, http://data.worldbank.org/indicator/SP.POP.TOTL.FE.ZS.

United Nations Economic Commission for Europe. 2007. The Gender Pay Gap. The World Bank. Accessed 6th November, http://siteresources.worldbank. org/EXTGENDERSTATS/Resources/pay_gap.swf.

Valentine, David. 2007. Imagining Transgender: An Ethnography of a Category. 
Article $\cdot$ Lewis

Durham: Duke University Press.

VicHealth. 2004. 'The Health Costs of Violence: Measuring the Burden of Disease Caused by Intimate Partner Violence. VicHealth. Melbourne. Accessed 6th November, https://www.vichealth.vic.gov.au/media-and-resources/publications/the-health-costs-of-violence.

World Economic Forum. 2015. 'The Global Gender Gap Report 2015'. World Economic Forum. Accessed 6th November, http://reports.weforum.org/globalgender-gap-report-2015/. 